\title{
$40 \mathrm{~m}$ PSC I형 철도교의 동적 성능 평가
}

\section{Experimental Performance Estimate of a 40m PSC I Girder for Railway Bridges}

\author{
여인호* \\ Inho Yeo
}

\begin{abstract}
Here we report the results of an experimental laboratory test to verify the applicability to railway bridges of a PSC I girder of which the upper flange thickness was increased to improve sectional performance. The thicker this flange is, the further upward the neutral axis is moved. If in this way the span length can be increased to $40 \mathrm{~m}$ long, the bridge may be constructed with four girders instead of five. Therefore, construction cost could be lowered by reducing the weight of the long span structure due to increased sectional efficiency. It was also necessary to be certain that the dynamic performance of this relatively flexible structure would be applicable to railway bridges. Therefore numerical analysis, as well as static and dynamic tests, was carried out for a full-size PSC I girder. Based on these results, it was verified that the performance of the PSC I railway bridge satisfied the performance criteria of the design code.
\end{abstract}

Keywords : Railway bridge, PSC-I girder, Laboratory test, Dynamic performance, Performance criteria

\begin{abstract}
초 록 기존의 도로 및 철도교에 널리 사용되는 PSC I 거더의 단면성능을 향상시키기 위해 거더 중앙부 상부 플랜지의 두께를 증대시켜 중립축을 상향으로 이동시키는 개념의 PSC I 거더의 철도교 적용을 위한 정/동적 성 능을 시험실 시험을 통해 확인하였다. 이 개념의 PSC I 거더는 단면의 합리적 활용으로 거더의 경간장을 $40 \mathrm{~m}$ 까 지 연장하였으며 기존의 복선 철도교에 5 주형이 사용되던 거더 본수를 4 주형으로 줄여 건설비를 절감할 수 있 다. 기존의 교량에 비해 장경간 경량화를 추구한 신형식 교량은 상대적으로 유연한 구조로 진동에 대해 사용성 측면에서 취약할 수 있으므로 동적성능에 대한 검토가 필요하다. $40 \mathrm{~m}$ 길이의 실물크기 거더 모형시험을 통해 정 /동적 물리량을 추정하고 이를 유한요소 해석결과와 비교하여 타당성을 입증한 후 철도교량의 전산해석을 통해 철도설계기준에서 요구하고 있는 각종 동적 성능기준치의 부합여부를 확인 검증하였다.
\end{abstract}

주요어 : 철도교량, PSC-I 거더, 실내시험, 동적거동, 성능기준

\section{1. 서 론}

우리나라의 철도 설계 속도는 일반철도 구간도 이미 $230 \mathrm{~km} / \mathrm{h}$ 이상으로 고속화 되어 있으므로 철도교량 설계시 이러한 속도의 영향도 고려되고 있다. 철도교량의 경제성은 $\mathrm{PC}$ beam 형태가 타 형식에 대해 현저히 높은 것은[1]주지 의 사실이며 PC beam 형태에 있어서도 다양한 형식[2]이 제 안되어 경쟁적으로 사용되고 있다. 그러나 기존 beam형태 의 철도교량 경간장은 최대 $35 \mathrm{~m}$ 정도로 최대 $50 \mathrm{~m}$ 정도까 지 활용되고 있는 도로교에 비하면 약 $70 \%$ 수준에 그치고 있다. 최근 $25 \mathrm{~m}$ 경간장의 PSC I 형 철도교는 현장계측을 통 해 사용성을 검증한 바가 있다[3]. PSC I 거더의 단면 효율 을 높여 경간장을 보다 더 확대하거나 형고를 낮춰 슬림화 하려는 시도는 지속적으로 이루어지고 있다[2]. 고강도 콘크 리트를 적용하는 방안[4], 온도 프리스트레싱 강판을 보강하

*Corresponding author.

Tel.: +82-31-460-5664, E-mail : ihyeo@krri.re.kr

(C) The Korean Society for Railway 2013

http://dx.doi.org/10.7782/JKSR.2013.16.5.394
여 효율을 높이는 방법[5], 최적화 기법을 통해 형고를 최 적화하는 방안[6]등의 연구가 있었다. 그러한 시도 중 하나 로 제안된 $40 \mathrm{~m}$ 경간장의 4주형 PSC I형거더 교량이, 고속 화가 현실이 된 국내 철도교량으로 활용되기 위해서는 동적 거동이 국내 기준을 만족하는지 검토되어야 한다. 도로교량 과 가장 구분되는 고속 연행 철도차량하중에 의한 동적 특 성 [7-9]은 철도교량의 가장 중요한 검토 항목이다. 본 논문 에서는 기존의 도로 및 철도교에 널리 사용되는 PSC I거더 의 단면성능을 향상시키기 위해 거더 중앙부 상부 플랜지의 두께를 증대시켜 중립축을 상향으로 이동시킴으로써 더 큰 긴장력을 도입할 수 있는 PSC I거더의 철도교 적용에 대한 적합성 검증을 목적으로 한다. 단면의 합리적 활용으로 거 더의 경간장을 $40 \mathrm{~m}$ 까지 연장하였으며 기존에 5 주형이 사용 되던 거더 본수를 4주형으로 줄여 건설비를 절감할 수 있 다. 기존의 교량에 비해 장경간 경량화를 추구한 신형식 교 량은 상대적으로 유연한 구조로 진동에 대해 사용성 측면에 서 취약할 수 있으므로 동적 성능에 대한 검토가 필요하다. $40 \mathrm{~m}$ 길이의 실물 크기 거더 모형시험을 통해 정·동적 물 리량을 추정하고 이를 유한요소 해석결과와 비교하여 타당 성을 입증한 후 철도교량의 전산해석 모델에 대해 실열차 하 


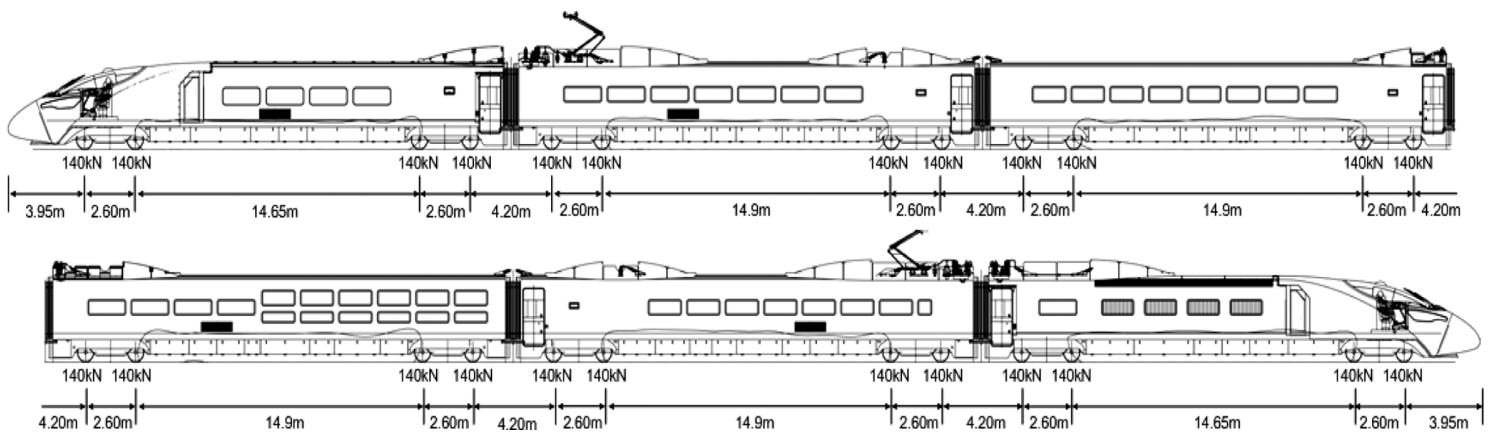

Fig. 1 Configuration of HEMU-430x
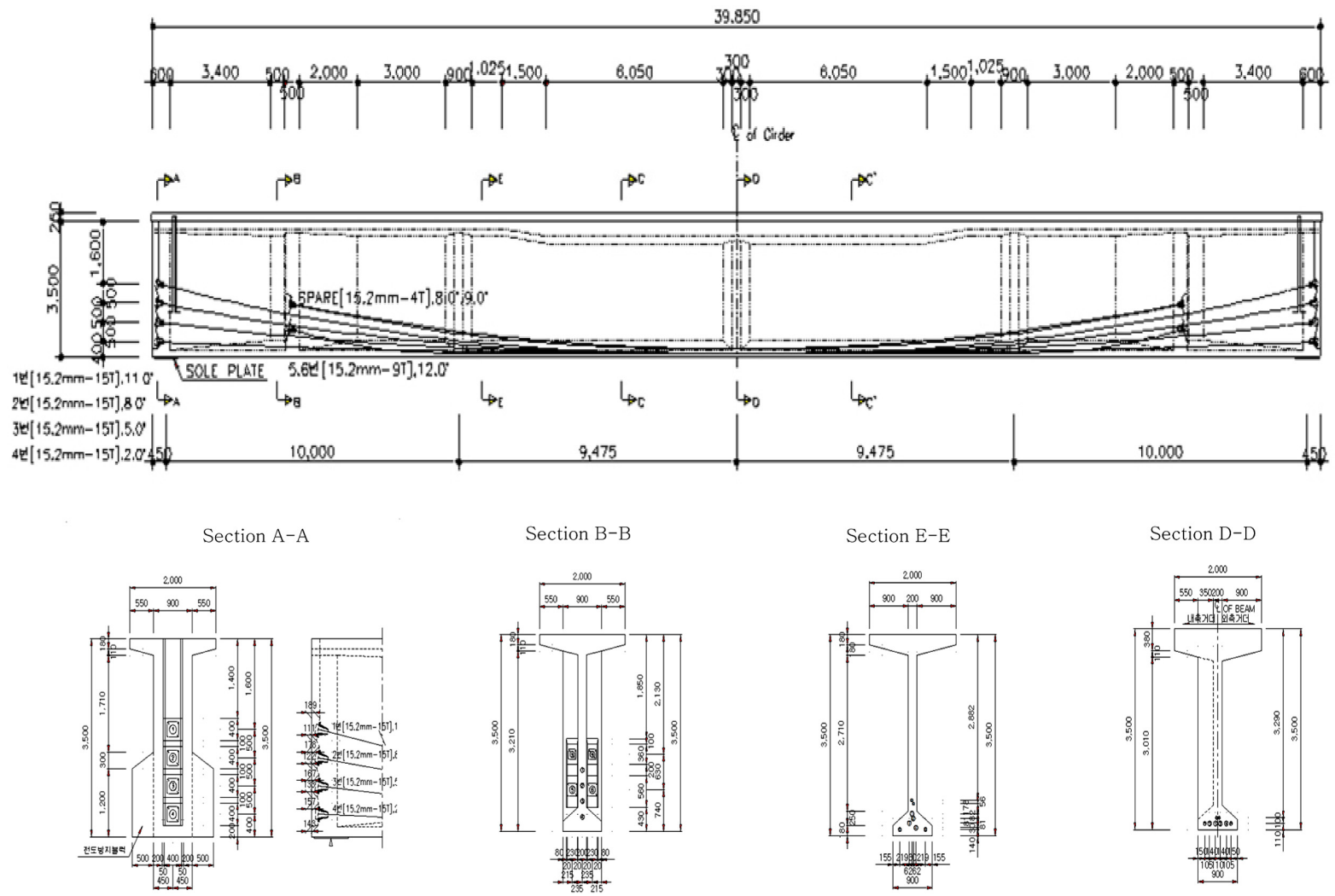

Fig. 2 Test specimen of 40m PSC I girder

중을 재하한 이동하중 해석을 통해 설계기준에서 요구하고 있는 각종 동적 성능 기준치의 부합여부를 검증하였다. 본 연구에서 검토되는 열차하중으로는 화물열차, 새마을호, KTX, 그리고 현재 개발되어 시험운행중인 HEMU-430x 열 차를 고려하여 국내에서 운행되거나 운행예정인 열차를 대 상으로 하였다. 또한 각 열차의 운행속도는 20 량 1 편성의 화 물열차[7]의 경우 $250 \mathrm{~km} / \mathrm{h}, 8$ 량 1 편성의 새마을 호[7]의 경 우 $300 \mathrm{~km} / \mathrm{h}, 20$ 량 1 편성의 KTX[10]의 경우 $400 \mathrm{~km} / \mathrm{h}$, 마지 막으로 Fig. 1 에 주어진 6 량 1 편성의 Hemu-430x의 경우 $450 \mathrm{~km} / \mathrm{h}$ 까지 $10 \mathrm{~km} / \mathrm{h}$ 씩 증속하여 고려하였다.

실내 시험 대상이 되는 $40 \mathrm{~m}$ 경간의 PSC I 거더는 Fig. 2 와 같으며, 이를 활용한 철도교량 단면은 Fig. 3에 주어져 있
다. 전산해석에 사용된 software는 범용 유한요소 해석 프로 그램인 LUSAS이며 이동하중 해석을 위해서는 10 차모드까 지의 고유치와 고유모드를 구한 후, 선형 탄성영역에서 거 동하므로 모드 중첩법에 의한 시계열 해석을 수행하였다. 실 내 정/동적 시험을 통해 하중-변위곡선으로부터 강성을 평 가하고, 고유진동수, 모드 형상, 감쇠비등 동특성을 추출한 후 전산 해석과 비교하여 수치해석 모델의 적합성을 확인하 였다. 이렇게 확인된 수치해석 모델을 이용하여 실제 철도 교량을 모델링하고 수치해석을 수행하여 철도교량의 동적 성 능기준 만족여부를 확인하였다. 동적 성능기준은 철도설계 기준[11]과 국내외 관련 규정을 조사하고 일반적으로 철도 교량 설계시 적용하고 있는 기준과 비교 검토하였다. 


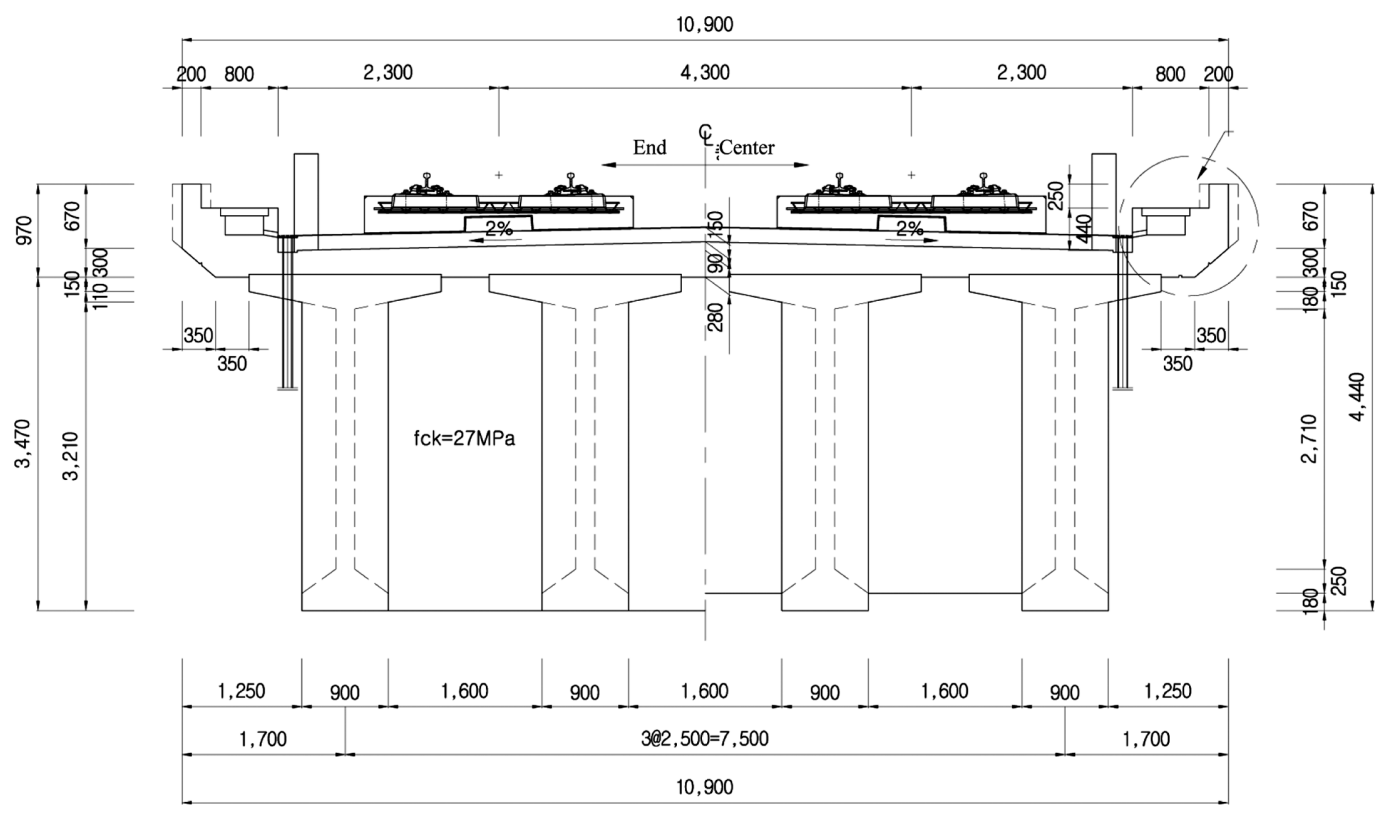

Fig. 3 Cross-section of railway bridge with 4 PSC I girders

\section{PSC I 거더 실물모형시험}

\section{1 정적시험}

본 논문에서는 철도교량용 PSC beam 형태의 거더에 기 반하여 $40 \mathrm{~m}$ 까지 경간을 확장한 거더에 대해 구조 성능을 검토하여 그 사용성에 대해 입증하고자 하였다. 특히 일반 적으로 $10.9 \mathrm{~m}$ 폭의 복선교량에는 5 주형이 기본으로 사용되 었으나, 이번 실물 모형은 4주형으로 합리화하여 형고는 다 소 높아지더라도 건설비를 최소화 할 수 있는 형태의 거더 에 대해 정/동적 성능을 검토하기 위하여 실내 시험을 수행 하였다. 철도교량에 사용될 PSC I 거더의 구조적 거동을 검 증하고자 Fig. 2에 보여진 실물 PSC I 거더 1본을 제작, 실 물 시험을 실시하였다. Fig. 4는 완성된 시험체와 시험장면 을 보여준다. 시험거더의 정적 성능을 평가하기 위해 단순 지지 조건으로 3 점 정하중 시험을 수행하였다. 1,2 차 강선 긴장에 따른 구조물의 응력분포를 측정하고, 이후, 슬래브 타
설, 증기양생, 그라우팅 작업을 실시하였으며, 양생이 완료 된 후 센서설치 및 배선 작업, 데이터로거 설치 작업을 수 행한 후 재하시험을 실시하였다.

시험거더에는 제작 단계에서 시험에 사용될 센서를 매립 설치 하였다. 중앙단면에서 응력변화를 확인하기 위해 거더 상하부에 철근게이지를 설치하였고, 중심부에서 약 $4 \mathrm{~m}$ 이 격을 둔 지점에 web을 따라 수직으로 철근게이지를 설치하 여 수직방향 응력 변화를 보고자 하였다. 또한 경간중앙과 경간 $1 / 4$ 지점에 처짐계측을 위한 처짐계를 설치하였고, 진동 시험시 동특성을 추출하기 위해 가속도계를 거더 하부 중앙 지점과 $2 / 6$ 지점에 2 개 설치하고 슬래브 상부에 $1 / 6,2 / 6$, 그 리고 중앙부에 3 개 설치 하였다.

거더 제작후 슬래브 타설전에 거더의 성능을 확인하기 위 하여 1차 시험이 진행되었고, 슬래브 타설 및 양생, 그리고 2차 강선의 긴장 및 그라우팅 후 거더와 슬래브의 합성거동 성능 확인을 위해 2차 시험이 수행되었다.
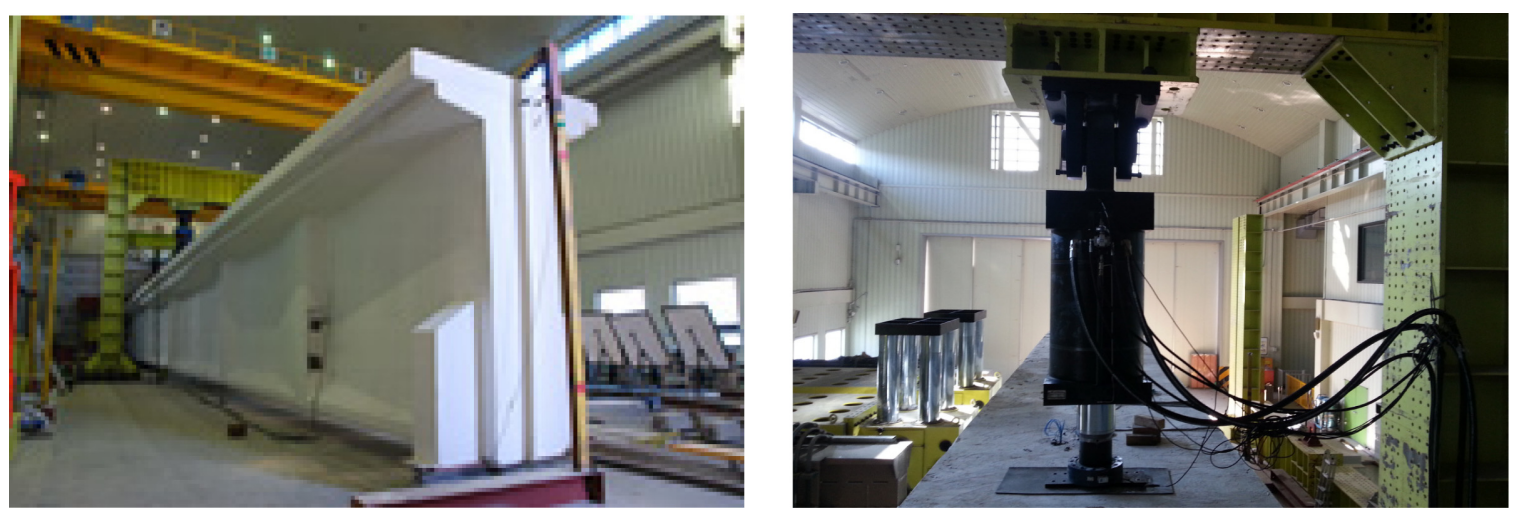

Fig. 4 Test specimen and static actuator 


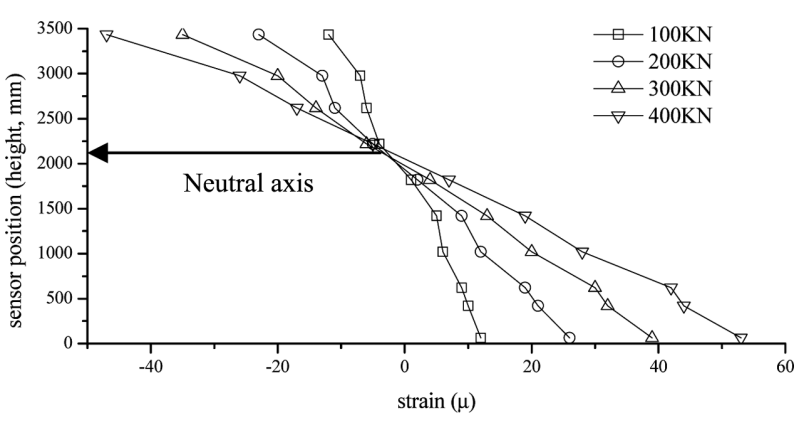

Fig. 5 Strain on the vertical section after 1st pre-stressing

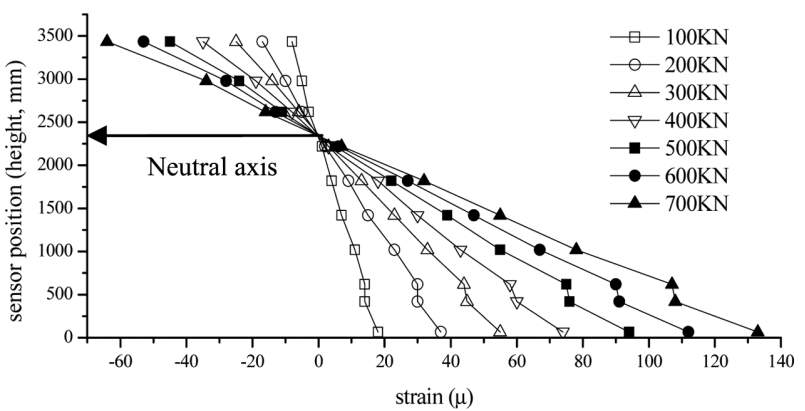

Fig. 6 Strain on the vertical section after 2nd pre-stressing

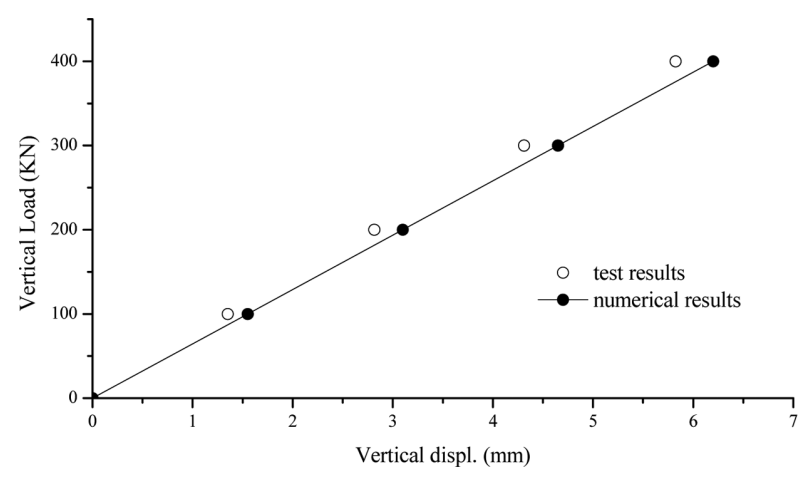

Fig. 7 Load-displacement after manufacturing the girder

Fig. 5는 거더제작 및 1 차강선 긴장 후에 단면 수직방향 으로 하중에 따른 변형율 분포이고, Fig. 6은 같은 단면에서 슬래브 타설 및 2차강선 긴장 후 하중에 따른 변형율 분포 이다. 두 그래프에서 단면을 따라 변형율이 선형분포를 가 지며 슬래브와 2차강선 긴장에 따라 중립축이 약 $20 \mathrm{~cm}$ 정 도 상부로 이동하고 있음을 알 수 있다.

Fig. 7은 거더 제작후 하중 변위 곡선으로 최대 $400 \mathrm{KN}$ 까 지 하중을 재하한 결과 수치해석결과보다 다소 작은 처짐량 을 보였으나 매우 유사한 처짐을 보여주고 있다. Fig. 8은 상 부슬래브 타설후 하중 처짐 곡선으로 특히 1차 계측시에는 사용하중까지, 그리고 2 차 계측시에는 균열이 충분히 진행 될 수 있는 하중까지 재하하였고, 이후 유지관리용 강선 긴 장후 거더의 거동을 확인하기 위해 엑츄에이터에서 허용할 수 있는 최대 하중까지 재하하였다. 그래프에서 보는 바와

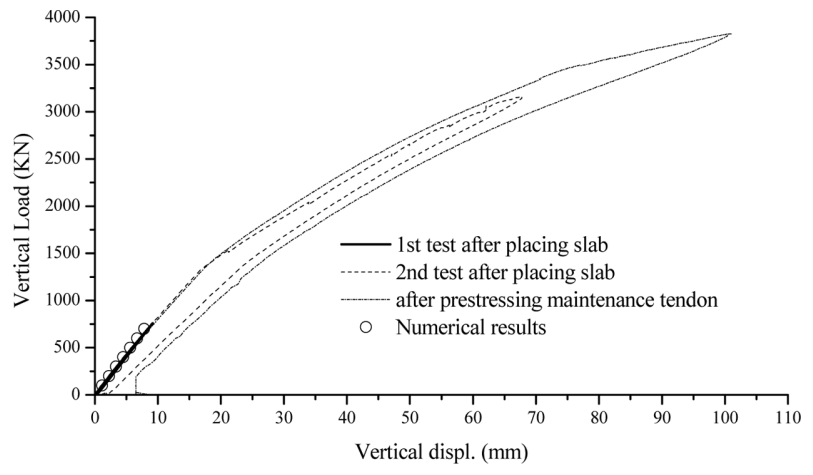

Fig. 8 Load-displacement at each test step

같이 사용하중까지는 시험치와 해석결과가 선형적으로 일치 하는 결과를 보여주고 이후 2 차 시험과 유지관리용 강선 긴 장후에도 거의 일치하는 거동을 보여 유지관리용 강선의 유 효성을 확인할 수 있었다.

\section{2 동특성 시험}

철도교와 도로교의 가장 큰 차이점 중 하나는 중량의 열 차 하중이 열차 바퀴를 통해 교량에 재하되는데 열차 속도 와 객차간격에 의해 좌우되는 유효 타격 간격에 따른 일정 한 주기로 하중이 재하된다는 점이다. 이는 열차가 통과하 는 동안 일정한 간격의 반복하중이 재하되는 것을 의미하고, 이로 인해 하중 재하주기와 구조물의 고유주기가 일치하는 경우 공진이 발생할 가능성을 항상 내포하고 있다. 이 반복 하중에 의해 발생할 수 있는 공진 또는 공진은 아니더라도 과도한 처짐과 가속도는 구조물의 안전성에 영향을 미칠 수 있고, 유도상/무도상 궤도의 안정성과, 특히 열차 승객의 승 차감에 더욱 안좋은 영향을 미치는 등 사용성에 문제를 일 으킬 수 있다. 이러한 열차의 반복하중을 받는 교량의 동적 거동을 정확히 분석하기 위해서는 교량의 동적 거동과 관련 되는 특성치를 정확히 반영하는 것이 매우 중요하다.

동특성 추출 시험 방법으로는 $180^{\circ}$ 의 위상차를 갖는 편심 질량을 회전시켜 가진시키는 가진기를 사용하는 방법, impact hammer로 자유진동시키는 방법도 있으나, 가진기를 이용하 는 경우 가진기 자체의 추가질량 그리고 회전체의 오차에 따 라 측정결과에 오차가 더해질 수 있다. 또한 impact hammer 에 의한 자유진동은 충격량의 크기가 구조물의 규모에 비해 작게 되는 경우 구조물의 전체를 진동시키기에 부족한 충격 량이 되어 구조물의 강성과 고유진동수가 다소 과대평가될 우려가 있다. 따라서 본 논문에서는 $40 \mathrm{~m}$ 실물거더 1 본에 대 해 50ton급 가력기를 이용하여 수 $m m$ 의 변위를 가한 후 순 간적으로 힘을 제거하여 자유진동을 유도하는 quick release 방식으로 고유진동수와 고유모드, 그리고 감쇠비를 측정하 였다. 본 시험에서는 초기 변위를 $2 \mathrm{~mm}, 5 \mathrm{~mm}, 7 \mathrm{~mm}$ 등 3 가 지 경우로 미소한 차이를 두고 발생시켰다.

Table 1에서 보는 바와 같이 초기 변위가 작은 경우 고유 진동수가 다소 크게 측정되었고, 가속도계 위치에 관계없이 
Table 1 Measured natural frequencies

\begin{tabular}{c|c|c|c|c|c}
\hline Initial displacement & ACC1 & ACC2 & ACC3 & ACC4 & ACC5 \\
\hline \hline $2 \mathrm{~mm}$ & 4.248 & 4.248 & 4.248 & 4.248 & 4.248 \\
\hline $5 \mathrm{~mm}$ & 4.102 & 4.102 & 4.102 & 4.102 & 4.102 \\
\hline $7 \mathrm{~mm}$ & 4.102 & 4.102 & 4.102 & 4.102 & 4.102 \\
\hline
\end{tabular}

Table 2 Measured damping ratio by logarithmic decrement

\begin{tabular}{c|c|c|c|c|c}
\hline & $\mathrm{n}$ & $y_{i}$ & $Y_{i+n}$ & $\delta$ & $\xi(\%)$ \\
\hline \hline \multirow{2}{*}{$2 \mathrm{~mm}$} & 15 & 0.033949 & 0.009095 & 0.087809 & 1.4 \\
\cline { 2 - 6 } & 10 & 0.033949 & 0.012666 & 0.098594 & 1.6 \\
\hline \multirow{2}{*}{$5 \mathrm{~mm}$} & 15 & 0.122250 & 0.021978 & 0.114402 & 1.8 \\
\cline { 2 - 6 } & 10 & 0.122250 & 0.043480 & 0.103377 & 1.6 \\
\hline \multirow{2}{*}{$7 \mathrm{~mm}$} & 15 & 0.168036 & 0.035051 & 0.104492 & 1.7 \\
\cline { 2 - 7 } & 10 & 0.168036 & 0.063498 & 0.097317 & 1.5 \\
\hline
\end{tabular}

일정한 값이 계측되었다. 이는 초기 변위를 작게 주는 경우 impact hammer에 의한 경우와 마찬가지로 전체 경간을 진 동시키기에는 다소 작은 가진력이 도입되기 때문으로 판단 된다. 따라서 충분한 가진력이 도입되었다고 생각되는 $5 \mathrm{~mm}$ 이상의 초기 변위시에 측정된 $4.102 \mathrm{~Hz}$ 를 1 차 고유진동수로 판 단하였다. 각각의 경우에 대해 감쇠비를 logarithmic decrement (식(1))로 측정해 본 결과는 Table 2에 주어져 있다.

$$
\delta=\frac{1}{N} \ln \left(\frac{y}{y+n}\right) \cong 2 \pi \xi \text { 그러므로, } \xi \cong \frac{\delta}{2 \pi}
$$

Table 2에서 보는 바와 같이 감쇠비 측정치는 다소간의 편 차가 발생하였으며 가장 작게 측정된 값이 $1.4 \%$ 임을 알 수 있다. 이는 Eurocode[12]와 철도설계기준(노반편)[11]에서 $\mathrm{PSC}$ 구조물에 대해 정하고 있는 $1.0 \%$ 보다는 큰 값으로 철 도 설계기준이 다소 보수적인 값을 설정하고 있음을 알 수 있다.

\section{3. 전산해석}

\section{1 시험거더 해석}

실내 시험을 통해 얻은 PSC I 거더의 거동을 확인하기 위 하여 시험체를 수치모델화하여 전산해석을 수행하였고, 시 험 거더가 철도교량의 주형으로 적용되었을 경우 열차의 이 동하중에 의한 동특성 해석을 수행하였다. 실물 구조물에 대
해 현장실험을 수행하면 가장 정확한 구조물의 거동을 얻을 수 있지만, 실험장비와 규모 그리고 비용등의 문제로 토목 구조물에 있어 대부분의 경우 실물시험이 불가능 한 것이 현 실이다. 이런 경우 유한요소 해석을 기반으로 하는 수치해 석은 간접적으로 매우 신뢰성 있는 결과를 얻을 수 있는 유 용한 방법이다. 아무리 정교하고 정밀하게 만들어진 실험모 델이라도 수치해석과 완전히 일치하는 결과를 얻을 수 없고, 유한요소모델링 특성상 실험모델과 정확히 일치할 수는 없 다. 다만 실험치와 수치해석결과와의 차이가 유의할 수준 이 하이고 수치해석결과가 다소 안전측이라는 것을 확인하면 수 치해석결과를 이용하여, 실험이 불가능한 구조물에 대한 신 뢰성을 확보할 수 있다. 시험체의 거동을 검증하기 위한 수 치해석에는 상용 유한요소 해석 프로그램인 LUSAS를 적용 하였다. 수치해석결과 주된 관심의 대상인 첫번째 연직 휨 모드의 고유진동수가 $4.168 \mathrm{~Hz}$ 로 시험치인 4.102 와 약 $2 \%$ 의 오차로 매우 유사한 값을 보여 수치해석 모델이 실제 실물 모형을 적절히 모사하고 있고 해당 모델을 이용한 열차 이 동하중 해석도 신뢰할만한 결과를 얻을 수 있다는 것을 알 수 있다. Fig. 9는 시험체 거더의 수치모델에 대해 고유치해 석을 한 결과로 5 차모드까지의 모드형상과 고유진동수를 보 여준다. 거더의 높이가 높고 상대적으로 폭이 좁아 1차모드 는 횡방향 휨모드가 나타나고 있다. 그러나 4 개의 거더로 폭 $10.9 \mathrm{~m}$ 의복선철도교를 시공한 후에는 수직방향 모드가 1 번 째 모드가 된다.

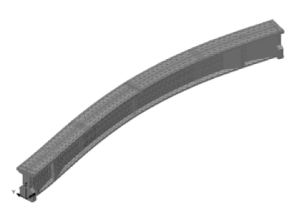

$2.6 \mathrm{~Hz}$

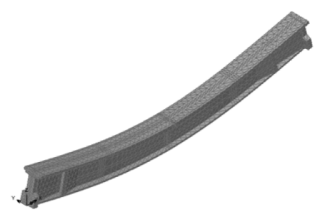

$4.186 \mathrm{~Hz}$

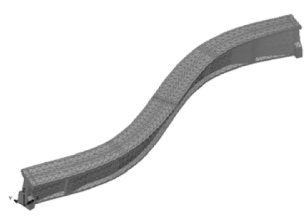

$8.327 \mathrm{~Hz}$

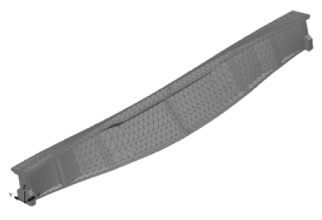

$11.614 \mathrm{~Hz}$

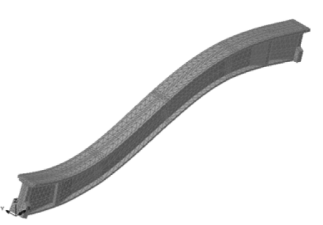

$13.032 \mathrm{~Hz}$

Fig. 9 Natural frequencies and mode shapes 
$40 \mathrm{~m} \mathrm{PSC}$ 형 철도교의 동적 성능 평가 한국철도학회논문집 제16권 제5호(2013년 10월) 399

\subsection{PSC 거더 철도교량 이동하중 해석}

$\mathrm{PSC} \mathrm{I}$ 거더 철도교량의 동적성능을 검증하기 위하여 8 량 1 편성 새마을호, 20 량 1 편성 화물열차, $\mathrm{KTX}$, 그리고 현재 개발되어 시험운행중인 KTX-Hemu 430x에 대하여 주행속 도별 동적해석을 수행하여 철도교량으로써의 타당성을 분석 하였다. 교량의 수치모델은 8절점 solid 요소를 사용하여 가 능한한 실물형상과 유사하게 모델링하고자 하였다. 열차의 모델링은 집중하중의 연행하중에 의한 모사를 하였다. 본 연 구에서 교량의 경간장은 $40 \mathrm{~m}$ 단경간 교량을 선정하였는데, 이는 앞선 실내 시험의 대상이었던 PSC I 거더를 적용하는 교량으로 기존의 $\mathrm{PSC}$ 형태의 거더 교량으로는 최장 교량이 된다. 대상 교량은 Fig. 3에 보인 단면을 가지고 있으며 그 전산해석 모델은 Fig. 10 과 같다. 지점조건은 단순지지를 가 정하였다. 이동하중 해석은 모드 중첩법을 적용하였고, 사용 한 모드는 첫번째 종/횡방향 모드를 포함하고 충분히 정확 성을 확보하기 위해 10 차 모드까지를 사용하였다. 1 차 모드 의 고유진동수는 $3.456 \mathrm{~Hz}$ 로 계산되었다. 감쇠비는 거더 시 험을 통해 얻은 값 중 가장 불리한 값인 $1.4 \%$ 를 적용하였다.

대부분의 일반철도교량의 경우 교량의 연직방향 후미강성 이 다른 강성에 비해 작기 때문에 교량의 자유진동해석(freevibration analysis)를 수행하면 연직 1차 휨모드가 첫 번째 고유진동모드로 발생한다. 이 첫번째 모드가 특정 차량 간격 을 갖는 열차하중에 의해 공진(resonance)및 공진소멸(resonance cancellation)을 발생시키는 열차 속도와 밀접한 연관을 갖는 다. 연행하중과 철도교량의 공진의 관계식을 이용하여 해석 교량의 공진을 야기하는 열차의 임계속도를 식(2)에 의해 구 하면 Table 3 과 같다.

$$
V_{c r}=\omega_{1} \times S_{e f f}
$$

여기서, $\omega_{1}$ : 교량의 첫번째 휨 고유진동수, $S_{\text {eff }}$ 열차의 지배 적 타격간격(객차간격)

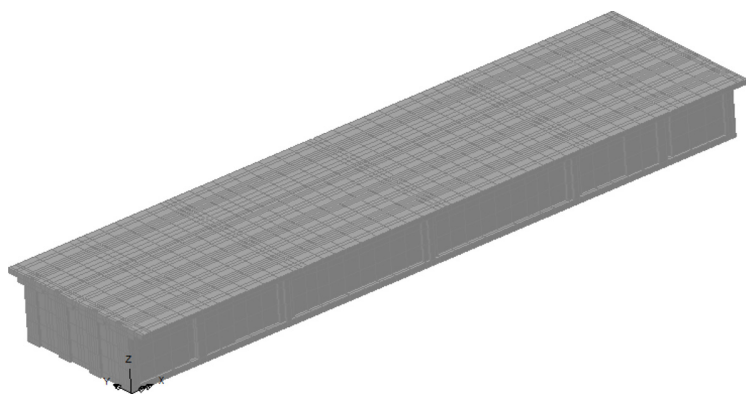

Fig. 10 Cross section of railway bridge with 4 PSC I girders
Table 3 Critical speed according to vehicle type

\begin{tabular}{c|c|c}
\hline & $\begin{array}{c}\text { Main beating } \\
\text { distance }\end{array}$ & Critical speed \\
\hline \hline Natural frequency $(\mathrm{Hz})$ & & $3.456 \mathrm{~Hz}$ \\
\hline Saemaul & $23.5 \mathrm{~m}$ & $292(\mathrm{~km} / \mathrm{h})$ \\
\hline Freight & $13.95 \mathrm{~m}$ & $174(\mathrm{~km} / \mathrm{h})$ \\
\hline KTX & $18.7 \mathrm{~m}$ & $233(\mathrm{~km} / \mathrm{h})$ \\
\hline KTX-HEMU430x & $21.7 \mathrm{~m}$ & $270(\mathrm{~km} / \mathrm{h})$ \\
\hline
\end{tabular}

기존에 운행중이 무궁화호의 경우 차량 제원이 새마을호 와 일치하므로 새마을호만 적시하였다. Table 3에 따르면 새 마을호의 경우 임계속도가 기존철도에서의 일반적인 최고 운 행속도 $(160 \mathrm{~km} / \mathrm{h})$ 보다 거의 2 배이고, 화물열차의 경우에도 일 반적인 화물열차 최고운행속도보다 훨씬 높은 임계속도를 가 지고 있다. 따라서 새마을호와 무궁화호 그리고 화물열차가 설계속도 이하로 운행되는 일반철도(기존철도)구간에서는 $40 \mathrm{~m}$ 경간의 PSC I 거더 교량에서 운행열차에 의한 공진 발 생위험이 전혀 없음을 알 수 있다.

$\mathrm{KTX}$ 와 Hemu-430x의 경우 설계속도가 $350 \mathrm{~km} / \mathrm{h}, 430 \mathrm{~km} / \mathrm{h}$ 이므로 $40 \mathrm{~m}$ 경간의 PSC I거더 철도교량에서의 임계속도가 설계속도 이내에 들어갈 가능성이 있다. 이 경우 철도설계 기준[11]에 따르면 고속.일반 철도 모두를 포함하는 철도 교량의 주행열차하중에 대한 주행안전성, 승차감 및 교량의 동적 안전성을 검토하도록 되어있다. 설계속도 $200 \mathrm{~km} / \mathrm{h}$ 이 상의 고속철도 교량은 일정간격의 연행하중 작용에 의한 공 진위험 등이 항상 존재하므로 모든 교량에 대하여 이 규정 에 의한 동적거동 검토를 필수적으로 수행한다. 실 운행열 차 하중에 의한 동적거동은 속도별 최대응답을 검토하며, 검 토항목은 상판의 연직가속도, 교량의 연직처짐, 상판의 면틀 림이다. 수치해석 결과는 Table 4와 Fig. 11 그리고 Fig. 12 에 정리되어 있다.

Fig. 11과 Fig. 12에서 알 수 있듯이 최대 연직가속도와 최 대 연직변위는 Table 3 에서 예측되었던 임계속도에서 발생 하고 있다. 해석결과에 의하면 연직처짐의 경우 $40 \mathrm{~m}$ 철도 교량의 최대 허용처짐은 $21.1 \mathrm{~mm}$ 인데 화물열차 주행시 $7.4 \mathrm{~mm}$, 새마을호 주행시 $3.6 \mathrm{~mm}, \mathrm{KTX}$ 의 경우 $5.7 \mathrm{~mm}$, 그리 고 $\mathrm{Hemu}-430 \mathrm{x}$ 의 경우 $2.9 \mathrm{~mm}$, 즉 각각 허용처짐량의 $35 \%$, $17 \%, 27 \%$, 그리고 $13 \%$ 수준이 발생하여 모두 안정적인 결 과임을 보여주고 있다. 상판 연직가속도에 대해서도 $\mathrm{KTX}$ 주 행시 최대 $0.158 \mathrm{~g}$ 가 발생하나, 자갈도상궤도의 허용치 $0.35 \mathrm{~g}$ 및 콘크리트 궤도의 허용치 $0.5 \mathrm{~g}$ 에 훨씬 못미치고 있음을 알

Table 4 Results of numerical analysis

\begin{tabular}{c|c|c|c|c}
\hline & Freigth & Saemaul & KTX & Hemu-430x \\
\hline \hline Max. vertical acceleration & $1.26 \mathrm{~m} / \mathrm{sec}^{2}$ & $0.705 \mathrm{~m} / \mathrm{sec}^{2}$ & $1.55 \mathrm{~m} / \mathrm{sec}^{2}$ & $0.158 \mathrm{~g})$ \\
& $(0.13 \mathrm{~g})$ & $(0.072 \mathrm{~g})$ & $5.7 \mathrm{~mm}$ & $\begin{array}{c}0.586 \mathrm{~m} / \mathrm{sec}^{2} \\
(0.0598 \mathrm{~g})\end{array}$ \\
\hline Max. vertical displacement & $7.4 \mathrm{~mm}$ & $3.6 \mathrm{~mm}$ & $0.012 \mathrm{~mm}$ & $2.9 \mathrm{~mm}$ \\
\hline Max. twist & $0.425 \mathrm{~mm}$ & $0.014 \mathrm{~mm}$ & $0.009 \mathrm{~mm}$ \\
\hline
\end{tabular}




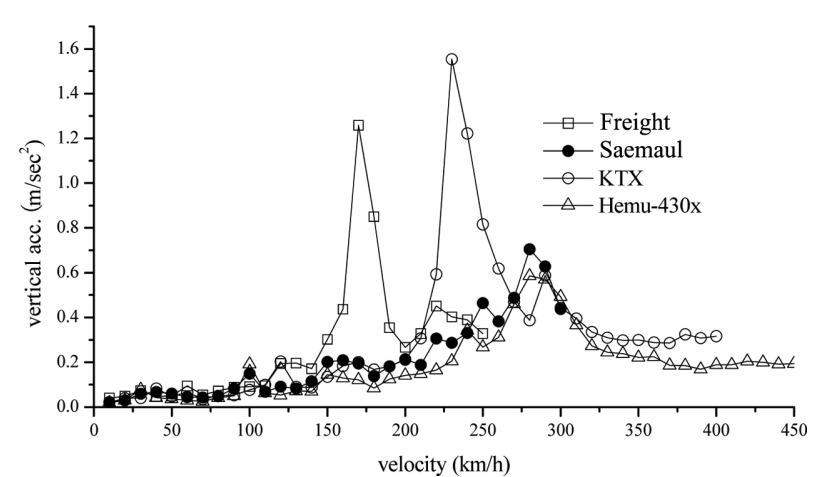

Fig. 11 Vertical acceleration according to vehicle velocity

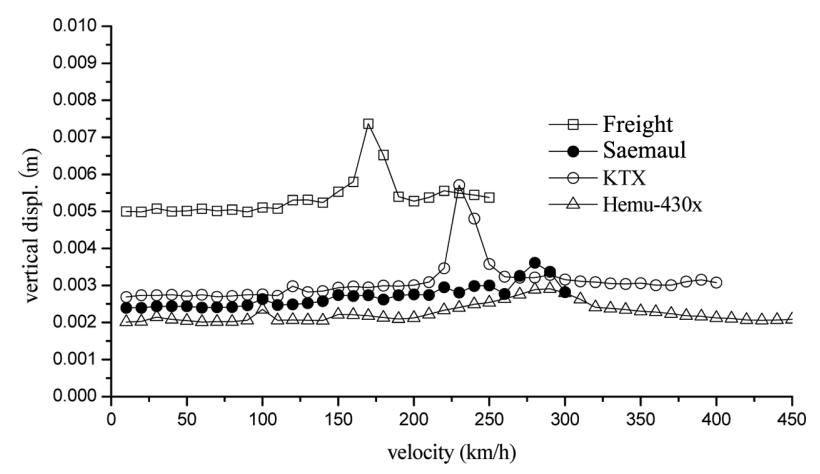

Fig. 12 Vertical displacement according to vehicle velocity vehicle

수 있다. 상판 면틀림의 경우에도 허용 면틀림의 최대 $35 \%$ 이내의 값이 발생하고 있음을 확인하였다.

\section{4. 결 론}

철도교량 건설비를 절감하기 방안으로 교량의 경간을 연 장하고 주형개수를 5 개에서 4 개로 줄이기 위해 제안된 PSC I 거더 철도교량의 동적성능 검증을 수행하였다. PSC I 거 더에 대해 실내 실물모형 시험을 통해 거더의 고유진동수와 감쇠비 등 동적 성능을 취득하였고, 상용 소프트웨어를 사 용한 전산해석을 통해 수치모델의 타당성을 확인한 후 PSC $\mathrm{I}$ 거더를 사용한 $40 \mathrm{~m}$ 단경간 철도교량에 대해 전산해석을 통해 동적 성능을 검증하였다. 최근 고속철도뿐 아니라 일 반철도에 대해서도 $230 \mathrm{~km} / \mathrm{h}$ 이상의 고속화가 추진되고 있 는 바 일반 철도교량에 적용되는 교량 형식에 대해서도 동 적 성능검증의 중요성이 부각되고 있다. 동적 성능 검증은 철도설계기준에서 제시하고 있는 실열차 하중을 재하하여 이 동하중 해석을 수행하였다.

Beam 거더 실물모형시험을 통하여 거더의 1 차 고유진동 수는 $4.102 \mathrm{~Hz}$, 그리고 감쇠비는 $1.4 \%$ 로 계측되었다. 1 차 고 유진동수는 수치모델의 모달해석결과인 $4.186 \mathrm{~Hz}$ 와 $2 \%$ 정도 의 오차로 잘 부합하고 있음을 알 수 있다. 구조물의 고유 진동수는 경간장의 미소한 오차, 계측 당시의 온/습도 등의 영향에 민감하므로 시험결과는 수치해석결과와 매우 잘 부
합하며 수치모델이 타당성을 확보하고 있다고 볼 수 있다. 따라서 이 거더모델의 수치모델을 활용하여 교량에 대한 수 치모델을 확보할 수 있다.

철도교량의 수치모델에 대해 동적해석을 수행하였다. 열 차하중으로는 현재 우리나라에 운행하고 있는 8 량 1 편성 새 마을호, 20 량 1 편성 화물열차, $\mathrm{KTX}$, 그리고 현재 개발되어 시험 운행중인 HEMU-430x을 고려하였다. 설계속도의 1.1 배까지 $10 \mathrm{~km} / \mathrm{h}$ 간격으로 동적해석을 수행하게되어 있음을 감안하여, 화물열차는 $250 \mathrm{~km} / \mathrm{h}$, 새마을호 $300 \mathrm{~km} / \mathrm{h}, \mathrm{KTX}$ $400 \mathrm{~km} / \mathrm{h}$, 그리고 $\mathrm{HEMU}-430 \mathrm{x}$ 는 $430 \mathrm{~km} / \mathrm{h}$ 까지 동적해석을 수행하였다. 해석결과에 의하면 연직 처짐, 상판 연직가속도, 그리고 면틀림 모두 허용치의 최대 $35 \%$ 이내의 값이 발생하 여 주행안전성을 확보하고 있음을 알 수 있다.

본 논문에서는 PSC I 거더의 실물 크기 부재시험을 통해 얻은 물리적 특성을 적용하여 수치해석을 통해 철도교량의 동적 해석을 수행하여 주행안전성을 확인하였다. 그러므로 실제 현장에 건설되는 철도교량과 정확히 일치하는 결과를 얻을 수는 없을 것이다. 다만 해석에 적용된 값들을 다소 보 수적인 값들을 적용하여 보다 안전측으로 해석이 되었고, 향 후 건설되는 해당 형식 교량의 현장 계측을 통해 보다 신 뢰성을 높일 수 있을 것으로 사료된다.

\section{References}

[1] T.-G. Lee, S.-W. Oa (2008) Comparison of Girder High and Construction Cost by Span in Various Types of Railway Bridge, Journal of the Korean Society for Railway, 11(5), pp. 471-476.

[2] K.-S. Kim, I.-H. Yang (2008) Development of New Type PSC Beam Girder Bridges in Korea, Magazine of the Korea Concrete Institute, 20(3), pp. 26-33.

[3] S.-H. Kang, T.-G. Choi, S.-J. Park, S.-I. Kim (2009) Dynamic Serviceability Estimation of the Simple Railway Bridge with PSC I Girder, Journal of the Korea Society of Hazard Mitigation, 9(1), pp. 65-71.

[4] J.S. Sim, I.H. Bae, J.K. Kim (1999) An Analytical Study for Design of Long-Span Prestressed Concrete Bridge I-Girder, Journal of the Korean Society of Civil Engineers, 19(I-4), pp. 581-590.

[5] S.-H. Kim, J.-H. Ahn, J.-H. Won, Y.-J. Park, (2006) A Study on PSC I girder using Thermal Prestressed Steel Plate(TPSC), Proceeding of KSCE Conference, Gwangju, pp. 1456-1459.

[6] S.H. Kim, J.M. Jeong, J.W. Seo, Y.H. Park (2006) The Evaluation of Structural Performation for PSC I Girder deigned by Optimizing, Proceeding of KSCE Conference, Gwangju, pp. 1423-1426.

[7] S.I. Kim, W.S. Chung, E.S. Choi (2005) A Study on the Optimal Span Length Selection of Conventional Railway Bridges considering Resonance Suppression, Journal of the Korean Society for Railway, 8(2), pp. 137-144.

[8] S.I. Kim, N.S. Kim, H.U. Lee (2006) Dynamic Performance Estimation of the Incrementally PSC Girder Railway Bridge by 
Modal Tests and Moving Load Analysis Journal of the Korean Society of Civil Engineers, 26(4A), pp. 707-717.

[9] R.-K. Min, D.-Y. Sung, Y.-G. Park (2012) Experimental Evaluation for Damping Ratio Limit of Railway Bridge according to Structure Types, Journal of the Korean Society for Railway, 15(2), pp. 154-161.

[10] S.H., Han, M.S. Bang, W.S. Lee (2010) A Study on Dynamic Capacity Assessment of PSC Box Girder High Speed Rail Bridges Using Time Series Load, Journal of the Korean Society of Civil Engineers, 30(3A), pp. 211-219.

[11] Korea Rail Network Authority (2011) "Railway Design Standard(Infrastructure)".
[12] EUROCODE 1 Part 2 (2006) "Actions on Structures : General actions -Traffic loads on bridges", European Committee for Standardization.

접수일(2013년 6월 7일), 수정일(2013년 7월 22일),

게재확정일(2013년 9월 22일)

InhoYeo : ihyeo@ krri.re.kr

Korea Railroad Research Institute, \#360-1, Woram-dong, Uiwang-si, Gyeonggi-do 437-757, Korea 